\title{
Scrotal Sarcoma
}

National Cancer Institute

\section{Source}

National Cancer Institute. Scrotal Sarcoma. NCI Thesaurus. Code C156283.

A sarcoma involving the scrotum. 